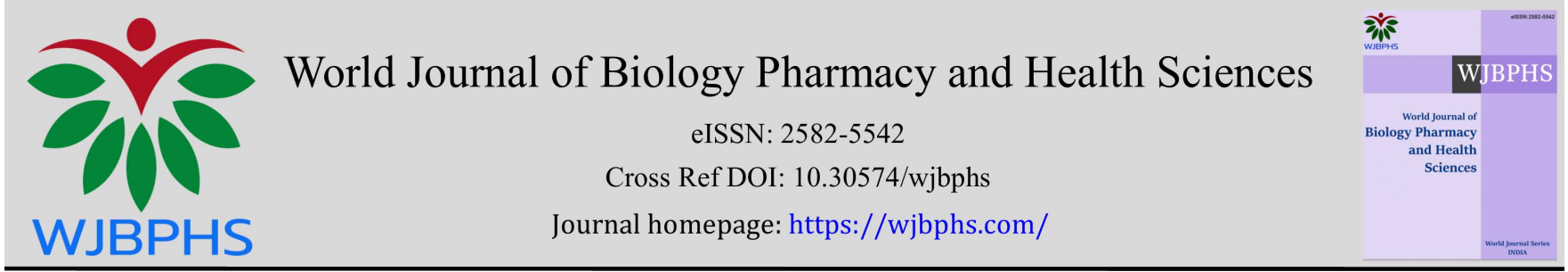

(RESEARCH ARTiCLE)

\title{
Chemical and microbial evaluation of water samples obtained from itinerant water vendors in Idi - Araba, Lagos State, Nigeria
}

\author{
Igbokwe Nwamaka Henrietta ${ }^{1,}{ }^{*}$, Ofomata Chijioke ${ }^{2}$ and Oli Angus Nnamdi ${ }^{3}$ \\ 1 Department of Pharmaceutical Microbiology and Biotechnology, Faculty of Pharmacy, CMUL Campus Idi-Araba, \\ University of Lagos, Lagos state, Nigeria. \\ 2 Department of Clinical Pharmacy and Pharmacy Management, Faculty of Pharmaceutical Sciences, Nnamdi Azikiwe \\ University Awka, Anambra State, Nigeria. \\ ${ }^{3}$ Department of Pharmaceutical Microbiology and Biotechnology, Faculty of Pharmaceutical Sciences, Nnamdi Azikiwe \\ University, Awka, Nigeria.
}

World Journal of Biology Pharmacy and Health Sciences, 2021, 06(03), 040-046

Publication history: Received on 18 June 2021; revised on 20 June 2021; accepted on 21 June 2021

Article DOI: https://doi.org/10.30574/wjbphs.2021.6.3.0065

\begin{abstract}
This study was carried out to investigate the potability of vendor waters mostly used by the urban dwellers in Idi-Araba, Lagos State, Nigeria. Sixteen water samples were analyzed, eleven from water vendors and four from source (Pumped Wells). One water sample from Nigerian bottling company was used as a control standard. Chemical analysis of the various water samples showed that they contained little and insignificant amount of toxic metals such as cadmium, nickel, lead and silver. Microbiological studies showed that vendor water was more contaminated than the source water and the contamination involved indicator and pathogenic organisms. All the organisms found in source water and more were found in vendor water. Susceptibility studies showed that of all the antibiotics used, the quinolones (Ofloxacin and Ciprofloxacin) and also aminoglycoside (Gentamycin) were the most effective antibiotics against the isolated microorganisms while Cloxacillin was the least active. The results of this investigation therefore suggests that the use of vendor and source waters in Idi-Araba appear unsafe for human consumption and domestic use. There is therefore the need for government and relevant authorities/organizations to provide potable water, stage awareness campaign and mass education on hygienic principles amongst the inhabitants of Surulere and the water vendors in particular.
\end{abstract}

Keywords: Microorganisms; Bacteria; Fungi; Itinerant; Contamination; E. coli

\section{Introduction}

Access to water is a basic human right [1] and water for human consumption must be free from all objectionable odor, turbidity, taste, enteric pathogenic bacteria or their indicators and must not fluctuate in its quality [2]. These days in the cities, water is circulated through piped systems [3]. The most convenient water supply, which is standard for all urban dwellers in wealthy countries, is water piped into the homes from a reliable piped-water network. A piped connection to the yard, however, can also constitute a fairly convenient service and may, as long as the water is forthcoming, support good hygiene practices and, given adequate drainage, safe water environments, In-house or yard connections are estimated to reach some 43 per cent of the urban population in Africa [4]. Water vending, an informal alternative access to urban water is therefore a symptom of failure in the piped system [5]. Poor governance is an increasingly popular explanation for bad water management and rapid urban growth exacerbates the problem [6]. Indeed, many piped systems in developing countries have not only had problems in matching population growth and urban sprawl, but are also having problems with the maintenance and operations of existing distribution networks,

\footnotetext{
* Corresponding author: Igbokwe Nwamaka Henrietta

Department of Pharmaceutical Microbiology and Biotechnology, Faculty of Pharmacy, CMUL Campus Idi-Araba, University of Lagos, Lagos state, Nigeria.
}

Copyright (C) 2021 Author(s) retain the copyright of this article. This article is published under the terms of the Creative Commons Attribution Liscense 4.0. 
hence, vendors often perform a parallel service [7]. In response to the limitations of water supply, 44\% of households have their own private Wells, and many rely on water vendors whose high prices amount to more than 30 percent of household income for the poor. As a result, a large proportion of poor households resort to drawing water from unhygienic source [8]. The general shortage of water supply that is a result of this low capacity utilization is then met by privately operated tankers, porters and privately owned boreholes and wells. This in turn has its own issues with regards to water purity standards, higher delivery costs and the ultimate impact on the state's water levels from the improper tapping of ground water reserves and wastage in its collection and delivery [9]. The safety of a privatelyowned, individual water supply, such as a back-yard well, rests in the hands of its owner [10]. It is estimated that water, sanitation and hygiene are responsible for $4.0 \%$ of all deaths and $5.7 \%$ of the total disease burden occurring worldwide. $[10,11]$. Women bear a disproportionate share of the inconvenience, while infants and small children bear a greater burden of disease $[11,12]$.

Lagos is a state surrounded by water and it can be assumed that the problem of water should not be faced. In practice however, reliable supply of potable water to many parts of the city is a big problem. This is because the lagoon is large and of course the ocean is salty [13]. It is infact difficult to find a reliable supply of river water in Lagos to purify which is why water from Ogun River (Iju) is the major source of water for purification for consumption in Lagos [14]. After purification, there is still the major problem of distribution and this explains why the supply of treated pipe-borne water in Lagos, is erratic with acute shortage experienced mostly in the dry months [15]. Ageing supply lines, water works and poor public electricity hamper the services of the water corporation, hence the corporation is operating at only $48 \%$ capacity, or only $36 \%$ of water demand. Only about 4 million of the 15 million population have access to piped water [8, 16]. A study in 2002 estimated that water, sanitation and hygiene were responsible for $4.0 \%$ of all deaths and $5.7 \%$ of the total disease burden occurring worldwide $[17,18]$. Diarrheal disease alone causes 2.2 million of the 3.4 million water-related deaths per year [19], ranking third among all causes of infectious disease deaths worldwide. Idi-Araba is a community in Lagos Mainland situated within Mushin and Surulere. In rainy seasons, there is so much water everywhere with little or none potable. In dry season, there is little or no water at all, thus water is a very good private commercial business in this area. Vendors sell water in buckets, Jerry-cans, Sachets "pure" etc.

\section{Material and methods}

\subsection{Collection of water samples}

A total of sixteen water samples were collected aseptically between January and March 2019 from Idi-Araba in Mushin Local Government Area, Lagos State. Out of the sixteen water samples, eleven were collected directly from the itinerant water vendors (from their water Jerricans) while four of the samples were collected directly from the source (Pumped wells). One sample used as a control standard was collected from representative of the Nigerian Bottling Company (NBC), using a sterile $500 \mathrm{~cm}^{3}$ sampling bottle. Separate similar containers were used for samples meant for physicochemical analysis. The collected water samples were stored at $4^{\circ} \mathrm{C}$ in the Department of Pharmaceutical Microbiology and Biotechnology Laboratory, Faculty of Pharmacy, College of Medicine Campus, Idi-Araba, University of Lagos for analysis.

\subsection{Sterilization of materials}

The materials (Sampling bottles, Agar and Broth media) used in this study were sterilized by autoclaving at $121^{\circ} \mathrm{C}$ for 15 minutes. The mouth of the Jerrican were flamed with automatic lighter for 30 seconds and water quickly poured from the Jerrican into the sterile bottle without allowing the Jerrican to touch the bottle before, during and after the water transfer. During collection of water from pumped wells, the taps were flamed for 30 seconds, water allowed to run for five minutes and sterile bottles were opened, the mouth flamed and water quickly collected from the already running tap. The mouth of the bottle and cover were flamed and closed immediately for analysis.

\subsection{Chemical evaluation of the water samples}

This was carried out in the Department of Chemistry Laboratory, Faculty of Science, University of Lagos, Akoka, Lagos. The water samples were digested to remove the organic materials and convert the metals present in the water into soluble forms [20]. To achieve this, $10 \mathrm{mls}$ of each of the water samples were measured into a $250 \mathrm{ml}$ conical flask and $1 \mathrm{ml}$ of nitric acid added into each of the flasks. This was then evaporated on a hot plate in a fume cupboard until the brown fumes disappeared. Each solution was made up to $20 \mathrm{mls}$ and filtered into a plastic bottle ready for Atomic Absorption Spectrophotometer (AAS) analysis using the Perkin Elmer Analyst 200. 


\subsection{Isolation and characterization of micro-organisms}

A 10-2 dilution of each water sample was cultured into nutrient agar and Sabouraud dextrose agar plates. The nutrient agar plates were incubated at $37^{\circ} \mathrm{C}$ for 24 hours while the Sabouraud dextrose agar plates were incubated at $25^{\circ} \mathrm{C}$ for 72 hours. The organisms obtained from Nutrient agar plates were subcultured into various diagnostic media -Tryptone Soy Agar (TSA), Salmonella-Shigella Agar (SSA), Eosin Methylene Blue Agar (EMBA), MacConkey Agar (MAC), and Manitol Salt Agar (MSA) for further characterization and identification of pure isolates using the NCCLS, 2003 method. The fungal organisms isolated from Sabouraud Dextrose Agar were further identified using their morphological characteristics.

\subsection{Antibiotic susceptibility of the organisms isolated from water samples}

The antibiotic sensitivity pattern of the microorganisms isolated from the water samples was determined using the NCCLS (2003) disk diffusion method [21]. Each of the test organisms, $103 \mathrm{cfu}$ was plated in TSA and incubated at $37^{\circ} \mathrm{C}$ for $24 \mathrm{hrs}$. Colonies from each organism was emulsified in normal saline to match the turbidity of $0.5 \%$ Mcfalan standard solution. Each suspension was then incubated at $37^{\circ} \mathrm{C}$ for $4 \mathrm{hrs}$ and $1 \mathrm{ml}$ of $1 \mathrm{X} 106 \mathrm{cfu}$ of each of the organisms was seeded into Mueller Hinton Agar prepared according to manufacturer's instruction. Antibiotic multi discs from Oxoid Biological Ltd were placed on the solidified Mueller Hinton Agar culture. The plates were incubated at $37^{\circ} \mathrm{C}$ for $24 \mathrm{hrs}$ after which they were examined and zones of inhibition recorded.

\subsection{Statistical analysis}

The Student's t-test was used to determine the statistical significant difference which was regarded as significant when $\mathrm{P}<0.05$. Every data was expressed as mean \pm standard deviation of the mean.

\section{Results and discussion}

Out of the 16 water samples examined (vendor and source), 13 were contaminated with different micro-organisms as shown in table 1.

Table 1 Organisms isolated from water samples (1-16)

\begin{tabular}{|c|l|}
\hline Samples & \multicolumn{1}{|c|}{ Organisms } \\
\hline 1 & E. coli \\
\hline 2 & E. faecalis, Chromobacter \\
\hline 3 & E. faecalis P. aeruginosa, \\
\hline 4 & E. faecalis \\
\hline 5 & Salmonella \\
\hline 6 & Shigella \\
\hline 7 & Shigella \\
\hline 8 & B. subtilis \\
\hline 9 & B.subtilis \\
\hline 10 & E.coli \\
\hline 11 & E. faecalis \\
\hline 12 & - \\
\hline 13 & - \\
\hline 14 & E. faecalis \\
\hline 15 & Bacillus, E.coli \\
\hline 16 & - \\
\hline
\end{tabular}

1-11=water samples from vendors; 13-16=water samples from source

$12=$ control standard from Nigerian bottling company; - = No organism found

The heavy metals were found in traces as shown in table 2 and Nickel was found present in all the water samples. The analysis showed that vendor waters were more contaminated than the source waters since all the organisms found in source waters were replicated in vendor waters and more even in higher microbial load concentrations as is observed 
in the microbial limit test in table 3. This could be an indication of unhygienic practices of collecting, storing and distributing water from the vendors. This suggests that continuous use of such waters (vendor and source) untreated exposes people to the risk of diseases such as bacillary dysentery typhoid fever, urinary tract infections bronchial pneumonia etc. The antibiotic sensitivity pattern of bacterial isolates is shown in table 4 . The organisms were found to be most sensitive to fluoroquinolones (Ofloxacin and Ciprofloxacin) and Gentamycin. aminoglycoside. Cloxacillin was the least effective as it showed mild sensitivity only to Salmonella. The high microbial load recorded from the waters is an indication of the presence of high organic matters and the dissolved salts in the waters which are usually a common feature for naturally untreated water [22]. The presence of E. coli also indicates fresh fecal contamination [23, 24] which renders the water unacceptable for human consumption and domestic use [25, 26].

Table 2 Concentration of heavy metals in the water samples

\begin{tabular}{|c|c|c|c|c|}
\hline $\begin{array}{c}\text { Water } \\
\text { Sample }\end{array}$ & $\begin{array}{c}\text { Cadmium } \\
\text { (ppm) }\end{array}$ & $\begin{array}{c}\text { Lead } \\
\text { (ppm) }\end{array}$ & $\begin{array}{c}\text { Nickel } \\
\text { (ppm) }\end{array}$ & $\begin{array}{c}\text { Silver } \\
\text { (ppm) }\end{array}$ \\
\hline 1 & 0.017 & - & 0.046 & - \\
\hline 2 & 0.02 & - & 0.048 & 0.081 \\
\hline 3 & - & - & 0.048 & 0.051 \\
\hline 4 & - & - & 0.041 & 0.163 \\
\hline 5 & - & - & 0.035 & 0.006 \\
\hline 6 & - & - & 0.04 & - \\
\hline 7 & - & - & 0.005 & 0.006 \\
\hline 8 & 0.052 & - & 0.035 & 0.034 \\
\hline 9 & - & - & 0.056 & 0.045 \\
\hline 10 & - & - & 0.057 & 0.034 \\
\hline 11 & - & 0.045 & 0.045 & 0.045 \\
\hline 12 & - & - & 0.067 & 0.002 \\
\hline 13 & - & - & 0.038 & 0.027 \\
\hline 14 & - & - & 0.076 & 0.014 \\
\hline 15 & - & 0.005 & 0.045 & 0.012 \\
\hline 16 & - & - & 0.076 & 0.032 \\
\hline
\end{tabular}

Table 3 Microbial limit test

\begin{tabular}{|c|c|c|c|}
\hline Samples & Dilution & No of Colonies & Actual No of Colonies (Cfu/ml) \\
\hline \multirow{2}{*}{1} & $1: 100$ & - & $2 \times 10^{2}$ \\
\cline { 2 - 4 } & $1: 10$ & 2 & $3 \times 10^{2}$ \\
\hline \multirow{2}{*}{2} & $1: 100$ & 3 & $1.68 \times 10^{2}$ \\
\cline { 2 - 4 } & $1: 10$ & 168 & $2 \times 10^{2}$ \\
\cline { 2 - 4 } & $1: 100$ & 2 & $1 \times 10^{2}$ \\
\hline \multirow{2}{*}{4} & $1: 10$ & TNTC & \\
\cline { 2 - 5 } & $1: 100$ & 1 & $1 \times 10^{2}$ \\
\hline \multirow{2}{*}{5} & $1: 10$ & TNTC & \\
\cline { 2 - 5 } & $1: 10$ & No growth & \\
\hline
\end{tabular}


World Journal of Biology Pharmacy and Health Sciences, 2021, 06(03), 040-046

\begin{tabular}{|c|c|c|c|}
\hline \multirow[t]{2}{*}{6} & $1: 100$ & 1 & $1 \times 10^{2}$ \\
\hline & $1: 10$ & 1 & $1 \times 10^{2}$ \\
\hline \multirow[t]{2}{*}{7} & $1: 100$ & 39 & $3.9 \times 10^{2}$ \\
\hline & $1: 10$ & 26 & $2.6 \times 10^{2}$ \\
\hline \multirow[t]{2}{*}{8} & $1: 100$ & 19 & $1.9 \times 10^{2}$ \\
\hline & $1: 10$ & 60 & $6.0 \times 10^{2}$ \\
\hline \multirow[t]{2}{*}{9} & $1: 100$ & 4 & $4 \times 10^{2}$ \\
\hline & $1: 10$ & 41 & $4.1 \times 10^{2}$ \\
\hline \multirow[t]{2}{*}{10} & $1: 100$ & No growth & No growth \\
\hline & $1: 10$ & 120 & $1.2 \times 10^{2}$ \\
\hline \multirow[t]{2}{*}{11} & $1: 100$ & 10 & $1.0 \times 10^{2}$ \\
\hline & $1: 10$ & 126 & $1.26 \times 10^{2}$ \\
\hline \multirow[t]{2}{*}{13} & $1: 100$ & No growth & No growth \\
\hline & 1:10 & No growth & No growth \\
\hline \multirow[t]{2}{*}{14} & $1: 100$ & 5 & $5 \times 10^{2}$ \\
\hline & $1: 10$ & 12 & $1.2 \times 10^{2}$ \\
\hline \multirow[t]{2}{*}{15} & $1: 100$ & 20 & $2.0 \times 10^{2}$ \\
\hline & 1:10 & 35 & $3.5 \times 10^{2}$ \\
\hline 16 & $1: 100$ & No growth & No growth \\
\hline
\end{tabular}

Table 4 Antibiotic susceptibility result of organisms isolated from water samples

\begin{tabular}{|c|c|c|c|c|c|c|c|c|c|c|c|c|c|c|}
\hline $\begin{array}{l}\text { Water } \\
\text { sample }\end{array}$ & Organism & Ery & $A m x$ & Cot & Gen & Aug & Tet & Cip & Lev & Cxc & Chl & Nit & Nal & Ofl \\
\hline 1 & E.coli & - & - & - & - & - & - & 18 & - & - & - & 15 & - & 10 \\
\hline \multirow[t]{2}{*}{2} & E. faecalis & 10 & - & - & 14 & - & - & 21 & - & - & - & - & - & 15 \\
\hline & Chromobacter & - & - & 20 & 15 & - & - & 20 & - & - & - & - & 20 & - \\
\hline \multirow[t]{2}{*}{3} & E. faecalis & - & - & - & 10 & - & - & - & 15 & - & 28 & - & - & - \\
\hline & P. aeruginosa & - & - & 15 & - & - & - & 25 & - & - & - & - & - & 25 \\
\hline 4 & E. faecalis & 10 & - & - & 22 & - & - & 20 & - & - & - & 7 & 10 & 13 \\
\hline 5 & Salmonella & - & 17 & - & - & 25 & & 30 & 18 & 15 & - & - & - & 24 \\
\hline 6 & Shigella & - & 15 & - & 18 & 22 & & 25 & 20 & & 18 & - & - & 24 \\
\hline 7 & Shigella & - & 13 & - & - & 22 & & 24 & 18 & & - & - & - & 20 \\
\hline 8 & B. subtilis & - & - & - & 20 & - & 17 & 19 & - & - & - & 17 & - & 12 \\
\hline 9 & B.subtilis & - & - & - & - & 20 & & 22 & - & - & - & 18 & - & 12 \\
\hline 10 & E.coli & - & - & 20 & 15 & & - & 20 & - & - & 15 & - & 20 & - \\
\hline 11 & E. faecalis & 8 & - & - & 10 & - & - & 18 & 15 & - & - & - & - & - \\
\hline
\end{tabular}




\begin{tabular}{|c|c|c|c|c|c|c|c|c|c|c|c|c|c|c|}
\hline & E.coli & - & - & - & - & 19 & - & 18 & - & - & - & 15 & 10 & 10 \\
\hline 12 & None & & & & & & & & & & & & & \\
\hline 13 & None & & & & & & & & & & & & & \\
\hline 14 & E. faecalis & & - & - & 22 & - & - & 20 & - & - & 17 & 7 & 10 & 13 \\
\hline \multirow[t]{2}{*}{15} & Salmonella & - & 18 & - & - & 23 & & 25 & 14 & & - & - & - & 27 \\
\hline & E.coli & & & & & & & & & & & & & \\
\hline 16 & None & & & & & & & & & & & & & \\
\hline
\end{tabular}

Keys: Amoxicillin=Amx, Cotrimoxazole $=$ Cot, Ntrofurantoin $=$ Nit, Gentamicin $=$ Gen, Nalidixicacid $=$ Nal, Ofloxacin $=$ Ofl, Augmentin $=$ Aug Tetracycine $=$ Tet, Erythromycin $=$ Ery, Amoxicillin $=$ Amx, Cotrimoxazole $=$ Cot, Gentamicin $=$ Gen, Augmentin $=$ Aug, Ciprofloxacin $=$ Cip , Levofloxacin $=$ Lev) Cloxacillin $=$ Cxc, Chloramphenicol $=\mathrm{Chl}$.

\section{Conclusion}

From the result obtained, it therefore appears unsafe using water obtained from itinerant vendors or water obtained from such wells as stated above without treatment because of microbial and chemical contamination. The people that have no choice but rely on such means of water supply should be educated on the need to employ various disinfection techniques which include boiling, Filtration, chlorination, using disinfectants/antiseptics etc. There is also the need for relevant authorities to provide potable water, stage awareness campaign and mass education on hygienic principles amongst the inhabitants of Surulere and the water vendors in particular.

\section{Compliance with ethical standards}

\section{Disclosure of conflict of interest}

The authors declare no conflict of interest

\section{References}

[1] Dawson DJ, Sartory DP. Microbiological Safety of Water. British Medical Bulletin. 2000; 56(1): 74-83.

[2] Marianne k, Gordon M. Informal water vendors and the urban poor in human settlement group. 2006.

[3] WHO and UNICEF. Global Water Supply and Sanitation Assessment 2000 Report. 2000.

[4] Anastasia Angueleotu-Marteau. Informal water suppliers meeting water needs in the periurban territories of Munbai, an Indian perspective in global changes and water resourses: confronting the expanding and diversifying pressures: xiith World Water Congress, montpellier: France. 2008.

[5] World Water Assessment Programme. Water for People. Water for Life. A Joint Report by the Twenty-three UN Agencies Concerned with Freshwater. United Nations Educational, Scientific and Cultural Organization (UNESCO) and Berghahn Books. 2003.

[6] Collignon B, Vézina M. Independent Water and Sanitation Providers in African Cities. Full Report of a Ten-Country Study. UNDP-World Bank Water and Sanitation Program, Washington D.C. 2000.

[7] Ademola A, Afeikhena J. Utility privatization and the poor: Nigeria in focus. HBS Global Issues papers N0.12 ENGLISH VERSION. 2004.

[8] Olumuyiwa OC. A publication of the Lagos Water Corporation (LSWC), reforming the water sector in Lagos State. 2006.

[9] Lamikanra A (1999). Nutritional requirements- Water. Essential Microbiology for Students and Practicioners of Pharmacy, Medicine and Microbiology. Ambra Books, Lagos.2nd ed. Chp. 1999; 1: 57.

[10] Alfry BO et al. Agriculture. In Facts and Trends - Water.WBCSD, 2nd edn. 2005; 5.

[11] Valipour M. Land use policy and agricultural water management of the previous half of century in Africa. Appl Water Sci. 2015; 5: 367-395. 
[12] Bartram J, Cotruvo J, Exner N, Fricker C, Glasmacher A. Significance of water in our industries. Drinking Water Resources Development In Encylopedia of Microbiology. Academic Press. San. 2003; 271.

[13] Argosy T. Organisational History in Lagos water Corporation. 2007.

[14] Berger PS, Clark RM, Reasoner DS. Water diego.2nd ed. 2000; 4: 898.

[15] David H. Water and electricity in Nigeria, A report commissioned by Public Services International (PSIRU). 2006.

[16] Turek A, Wieczorek K, Wolf WM. Digestion Procedure and Determination of Heavy Metals in Sewage Sludge-An Analytical Problem. 2019; 11(6): 1753.

[17] Rahman MS, Salehin MF, Jamal M, Parvin A and Alam MK. Antibacterial activity of Argemone mexicana L. against water borne microbes. Res.J.Med. plant. 2011; 5: 621-626.

[18] Shahedur R, Anowar KP, Rezwanul I. Identification and quantification of Escherichia coli from drinking water in Bangladesh. International Journal of Microbiology and Immunology Research. 2013; 1(4): 047-051.

[19] Sharma A and Bhattacharrya A. Drinking water contamination and treatment techniques. Applied water Science. 2017; 7: 1043-1067.

[20] National Committee for Chemical Laboratory Standards (NCCLS 2003). Performance Standards for Antimicrobial Sensitivity Testing.12th International Symposium.M100-S12, Wayne P,A.

[21] Onifade AK. Antibiotic Sensitivity Profile of Human Pathogenic Microbes from Different Water sources in Akure Metropolis, Ondo State Nigeria. Env. Research Journ. 2008; 2(3):104-106.

[22] George JJ, Robert I, Bandler R. Enumeration of Escherichia coli and coliform bacteria in Bacteriological Analytical Manual of the U.S. food and Drug Administration. 2002.

[23] Chao KK, Chao CC, Chao WL. Evaluation of Colilert-18 for detection of coli forms and Escherichia coli in Subtropical water. Applied Environ.Microbial. 2004; 70: 1242-1244.

[24] EFFIONG MU, ISAAC IN. Comparative study of the bacterial load and species diversity in the african catfish (clarias gariepinus) cultured in contrasting aquaculture tanks in uyo, Nigeria. Animal Research International. $2019 ; 16(3): 3443-3449$.

[25] Feachem RG. Drinking water Qualuity.2nd ed. Environ. Health Engineer in Trop. 2001; 78-92.

[26] Gaurav S, Ram NB, Gaurav K, Abhay R. Microbial indicators, pathogens and methods for their monitoring in water environment. Journal of Water \& Health. 2004; 13(2): 319-339. 